\title{
Physical-biological coupling in Monterey Bay, California: topographic influences on phytoplankton ecology
}

\author{
John P. Ryan*, Francisco P. Chavez, James G. Bellingham \\ Monterey Bay Aquarium Research Institute, 7700 Sandholdt Road, Moss Landing, California 95039-9644, USA
}

\begin{abstract}
Physical-biological couplings impacting phytoplankton ecology are examined with synoptic, high-resolution observations of Monterey Bay, California. Influences of submarine canyon and shelf break topography on the physical-biological couplings are supported by 2 case studies. In the first case study, benthic-pelagic coupling was observed in southern shelf waters where a turbid plume extended from the bottom at $\sim 60 \mathrm{~m}$ deep to the base of a phytoplankton layer centered at $\sim 10 \mathrm{~m}$ deep. The alongshelf scale of the plume ranged from $\sim 5 \mathrm{~km}$ near the bottom to $\sim 1 \mathrm{~km}$ at its intersection with the phytoplankton layer. In situ and remote sensing data support the influence of Monterey Canyon on circulation forcing the benthic-pelagic coupling. In the second case study, a frontal zone and adjacent waters were rapidly surveyed over $\sim 20 \mathrm{~km}^{2}$ of the northern shelf. The front was associated with an isopycnal ridge/trough structure, surface slick, and frontal eddy $<1 \mathrm{~km}$ in diameter. The magnitude and vertical location of a chlorophyll maximum layer were closely coupled with the physical environment through the frontal zone. The layer was dispersed by the isopycnal ridge and frontal eddy, and concentrated in the isopycnal trough and along the periphery of the eddy. Influence of an internal wave generated by interaction of tidal currents with the shelf break is supported by the observed surface slick, measured water velocities, and the proximity and orientation of the shelf break. Significant and persistent influences of topography on phytoplankton ecology in Monterey Bay are indicated.
\end{abstract}

KEY WORDS: Physical-biological coupling $\cdot$ Topographic influence $\cdot$ Fronts $\cdot$ Eddies $\cdot$ Phytoplankton Benthic-pelagic coupling · Submarine canyons · Autonomous underwater vehicle

Resale or republication not permitted without written consent of the publisher

\section{INTRODUCTION}

Along the eastern margin of the North Pacific is one of the major coastal upwelling systems in which productivity is enhanced by upwelled nutrients (Ryther 1969, Barber \& Smith 1981). Satellite sea surface temperature (SST) and chlorophyll images illustrate the coastal upwelling phenomenon and associated phytoplankton response (Fig. 1). Recently upwelled waters are distinguished by their relatively cold SST, and after sufficient time for phytoplankton response to upwelled nutrients these waters are distinguished by high concentrations of chlorophyll. Influences of mesoscale circulation on the distributions of water masses and phytoplankton are described by the structures of eddies and filaments in the images. Within this productive and dynamic coastal upwelling system lies Monterey Bay, California. Time series observations from ships and moorings in the Monterey Bay region have augmented understanding of ecosystem variability across a wide range of temporal scales in physical forcing, including seasonal, El Niño, and the Pacific Decadal Oscillation (Pennington \& Chavez 2000, Chavez et al. 2002, 2003), as well as development and testing of ecosystem models (Service et al. 1998, Kudela \& Chavez 2000, Olivieri \& Chavez 2000).

Seafloor topographic effects on circulation and mixing significantly influence coastal and open ocean environments and the exchanges between them, and understanding these effects remains a primary chal- 

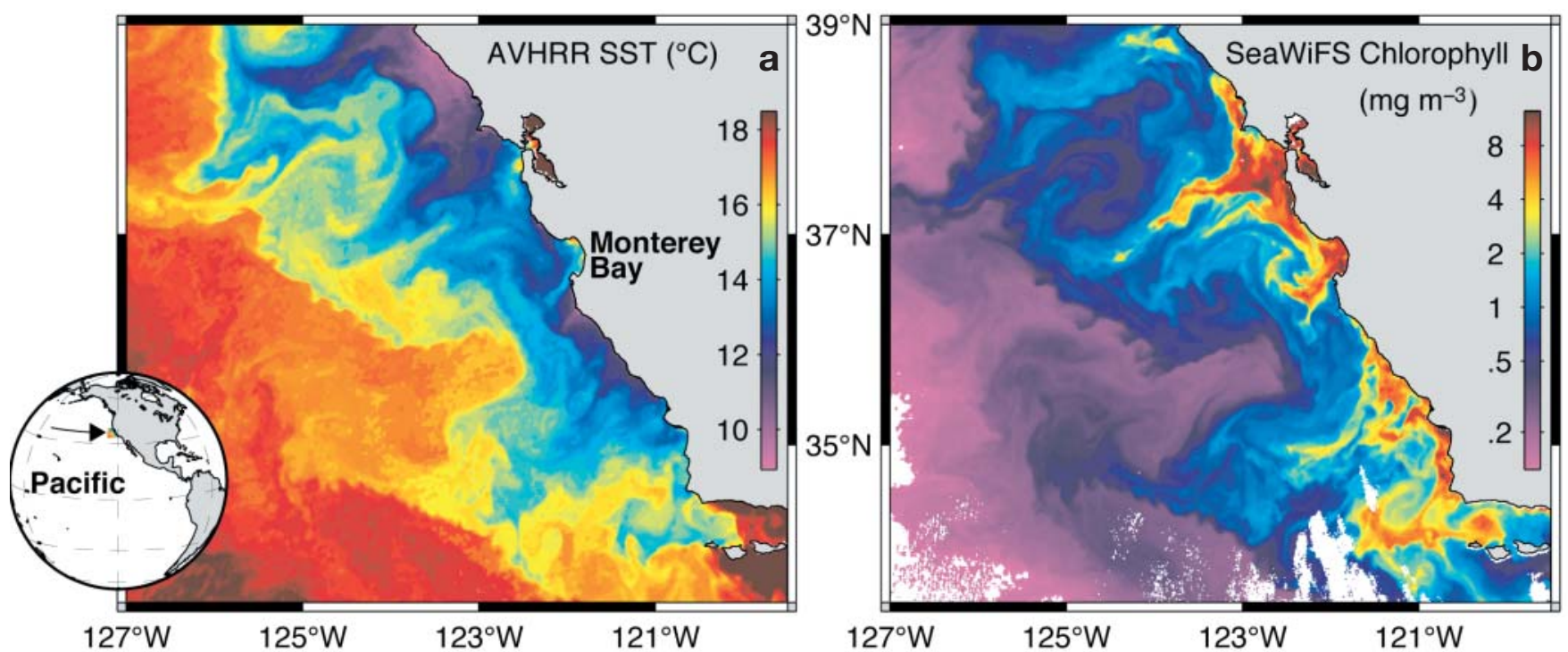

Fig. 1. Satellite remote sensing imagery of the central California Current upwelling system. (a) Sea surface temperature (SST) from the Advanced Very High Resolution Radiometer (AVHRR) on August 14, 2000, and (b) surface chlorophyll from the Sea-viewing Wide Field-of-view Sensor (SeaWiFS) on August 16, 2000

lenge in ocean science. The potential influence of sea floor topography on the ecology of Monterey Bay is greatly enhanced by the presence of Monterey Canyon, which extends from the deep ocean outside the bay nearly to the coast in the center of the bay (see Fig. 2). Case studies presented here from northern and southern shelf waters support the importance of the canyon and shelf break on shelf ecology through advective and internal wave processes.

Up-canyon flow, evident in observations and model studies, represents a major influence on the ecology of adjacent shelf waters through the movement of deep, nutrient-rich waters. Historical observations of deep current measurements in Monterey Canyon suggest predominantly up-canyon flow (reviewed by Breaker \& Broenkow 1994). Persistence of dense, nutrient-rich waters on the shelf off southern Vancouver Island has been associated with topographic steering of alongshore flows up Juan de Fuca Canyon (Freeland \& Denman 1982, Freeland \& McIntosh 1989). A model study by Allen (1996) found that the presence of a canyon enhances onshore (up-canyon) flow by an order of magnitude. A model study by Klinck (1996) found that the direction of flow relative to the canyon is a primary determinant of canyon-influenced circulation. Topographic influence on alongshore flows typical of upwelling conditions along the NE Pacific margin creates up-canyon flow, upwelling at the canyon head, and strong exchange across the shelf break.

Amplified internal wave activity over canyons can also influence shelf ecology by augmenting vertical and horizontal fluxes of nutrient-rich waters. Compared with the open ocean, the internal wave field in
Monterey Canyon is nearly an order of magnitude more energetic (Kunze et al. 2002). The large amplitude $(>100 \mathrm{~m})$ internal tide in upper Monterey Canyon pumps deep, nutrient-rich waters from the canyon onto the shelf; this process is estimated to account for one third of the primary production in Monterey Bay during the non-upwelling season (Shea \& Broenkow 1982).

Owing to rapidly changing conditions, widely ranging scales of ecosystem structure and processes, and complex physical-chemical-biological relationships, continental shelf waters present difficult challenges for observation of processes and their consequences. Resolution of processes requires observations having multidisciplinary scope and high spatial and temporal resolution. High-resolution, multidisciplinary observations in diverse marine environments are being enhanced by autonomous underwater vehicles (e.g. Bellingham 1997, Nadis 1997, An et al. 2001, Stansfield et al. 2001, Zhang et al. 2001, Brierley et al. 2002, Yu et al. 2002). Since 1999 the Monterey Ocean Observing System (MOOS) has supported development and application of autonomous underwater vehicles (AUVs) for coastal ocean research. During the MOOS Upperwater-column Science Experiment (MUSE) in August 2000, AUVs were applied to studies of complex processes in Monterey Bay and adjacent waters (Matthews \& Johnson 2001, Fitzwater et al. 2003). The case studies we present here are based on MUSE observations made with a multidisciplinary mapping AUV. This method of observation permitted unprecedented resolution of complex ecosystem structure by which processes could be examined. 


\section{MATERIALS AND METHODS}

Three methods of observation contributed to the case studies presented here: (1) AUV surveys, (2) moored and shipboard Acoustic Doppler Current Profiler (ADCP) measurements of water velocity, and (3) airborne SST remote sensing.

AUV operation, sensors and data processing. The AUV used during MUSE, an Odyssey IIb (Bellingham 1997, Yu et al. 2002), was operated from the RV 'Point Sur' each day from August 24 through August 31, 2000. AUV surveys were made in the region of a coastal upwelling filament north of Monterey Bay (Fitzwater et al. 2003), across a frontal zone outside Monterey Bay, and on the Monterey Bay shelf. Results from the Monterey Bay shelf surveys conducted on August 30 and 31 (Fig. 2) are the topic of this paper.

Control parameters for each AUV mission were programmed on the ship and sent to the AUV by radio. The core AUV mapping pattern used was the vertical section, in which the vehicle executes a vertical sawtooth flight pattern between upper and lower depth boundaries. For the shelf surveys, the upper boundary was set at $3 \mathrm{~m}$ deep and the lower boundary at $10 \mathrm{~m}$ above the bottom. Bottom detection was accomplished by a $200 \mathrm{kHz}$ sonar altimeter. Traveling at $\sim 1$ to $1.5 \mathrm{~m}$ $\mathrm{s}^{-1}$, the AUV covered horizontal scales of $\sim 3.6$ to $5.4 \mathrm{~km}$ $\mathrm{h}^{-1}$. The southern shelf survey of August 30 was a single vertical section (A in Fig. 2). During the northern shelf survey of August 31, multiple vertical sections

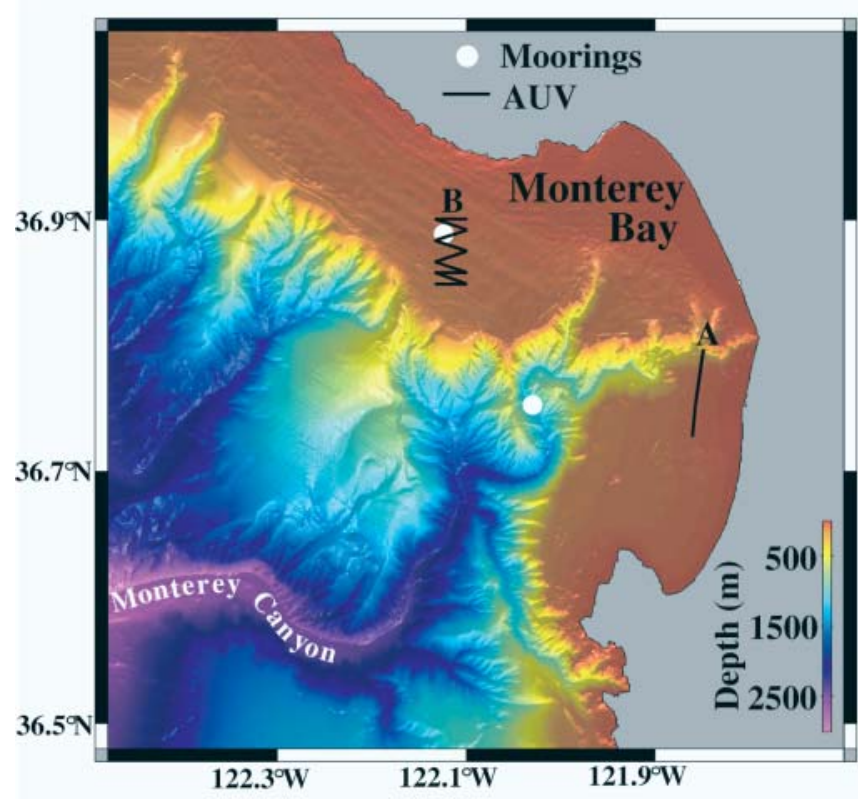

Fig. 2. Sea floor topography of the Monterey Bay region and locations of moorings and AUV surveys from which data are presented. AUV Survey A was conducted on August 30, 2000. AUV Survey B was conducted on August 31, 2000 were used to survey a volume through a frontal zone and adjacent waters. The front was located using the underway surface mapping system on the RV 'Point Sur'. The AUV was deployed north of the front and was programmed to progress southward in a series of vertical sections, each beginning at the prescribed eastwest boundaries (B in Fig. 2). Enhanced spatial resolution in the frontal zone was achieved by more closely spaced sections toward the southern end of the survey.

Geographic location of the AUV required (1) determination of the ship position using the ship's Global Positioning System, and (2) determination of the bearing and range from the ship to the AUV using a Trackpoint II ultra-short baseline system and the ship's gyro heading. AUV geographic locations were determined at the start and end of the missions. A 3-dimensional track of the vehicle through space was determined by dead-reckoning for the submerged portion of the vehicle's run. The required information for dead-reckoning was provided by the vehicle's propeller rotational speed, which allowed speed through the water to be computed, and the Crossbow attitude and heading reference system, which measured vehicle orientation. Depth was determined from the Paroscientific pressure sensor. The effect of currents was assumed to be uniform across the vehicle trajectory, allowing the dead-reckoned track to be corrected so that the start and end of the dead-reckoned track matched the respective GPS positions. A simpler analysis was used for vehicle missions conducted at a constant heading, with positions computed by linear interpolation between start and end points. Currents were light for the described AUV missions, implying small distortion of the AUV trajectories.

The AUV was equipped to measure pressure, temperature, conductivity (Sea-Bird Electronics: SBE-3S thermometer and SBE 4 conductivity sensor), oxygen (SBE 43), $\mathrm{pH}$ (SBE 18), chlorophyll fluorescence (WET Labs WETStar fluorometer), and optical backscatter (WET Labs Light Scattering Sensor). The pressure sensor was at the vehicle nose. The optical backscatter and $\mathrm{pH}$ sensors were mounted at the vehicle nose with sensor heads protruding slightly forward of the vehicle fairing. A plumbing intake was positioned at the nose to supply water serially to the CTD, fluorometer, and oxygen sensors; flow was forced by an SBE 5 pump. To align the measurements in the plumbed circuit with the pressure measurement, it was necessary to account for time lags due to flow of water from the intake to the sensors. Lags were calculated from pump flow rate and volume of the plumbing system between intake and sensor.

The CTD and oxygen sensors were calibrated by the manufacturer shortly before the experiment. Oxygen was calculated according to the algorithm of Owens \& Millard (1985). The pH sensor was calibrated in the lab before and after the experiment using National Bureau 
of Standards buffer solutions at pH of 4, 7 and 10. Measurements from the optical sensors are presented in relative units, following $\mathrm{Yu}$ et al. (2002): relative fluorescence units (RFU; $1 \mathrm{RFU}=1 \mathrm{~V}$ output signal) and relative backscattering units $(\mathrm{RBU} ; 1 \mathrm{RBU}=1 \mathrm{~V}$ output signal).

To illustrate a chlorophyll maximum layer observed within the northern shelf volume survey we used a chlorophyll fluorescence isosurface whose value was determined by analysis of the entire survey. Specifically, (1) examination of the individual vertical sections showed that the layer followed a common isopycnal throughout the domain, so mean fluorescence was computed on isopycnals, (2) the maximum positive vertical gradient in mean fluorescence was identified, and (3) the mean fluorescence value coincident with the maximum vertical gradient was used as the isosurface value identifying the layer.

Velocity measurements. ADCP water velocity measurements from 2 moorings (Fig. 2) and from the AUV tending ship, the RV 'Point Sur', were used to describe circulation patterns related to the physical-biological coupling events mapped by the AUV. The first mooring is a long-term MOOS mooring located at the mouth of the bay over Monterey Canyon. This mooring has a downward-looking RDI Long Ranger ADCP that provides velocity measurements between 20 and $500 \mathrm{~m}$ deep. The second source of moored velocity measurements was an upward-looking RDI Workhorse Sentinel $300 \mathrm{kHz}$ ADCP deployed on the outer northern shelf for MUSE. A $300 \mathrm{kHz}$ RDI vessel-mounted ADCP provided velocity measurements from the RV 'Point Sur'.

Airborne SST remote sensing. Due to persistent cloud cover over the Monterey Bay region there was no clear satellite ocean color or SST imagery of the bay during the period of shelf AUV surveys. However, SST coverage of Monterey Bay and adjacent waters during much of the MUSE period was accomplished by lowaltitude $(130 \mathrm{~m})$ aircraft overflights (Ramp et al. 2005). An aircraft SST map from the same day as one of the AUV surveys is presented.

\section{RESULTS AND DISCUSSION}

\section{Benthic-pelagic coupling}

On August 30 an AUV survey from the head of Monterey Canyon onto the southern shelf revealed benthic-pelagic coupling. The survey transected a plume of relatively cool SST (Fig. 3a), indicative of waters upwelled or vertically mixed to the surface. Daily maps of SST during August 27 to 30 do not indicate that the cool surface waters were upwelled outside the bay and transported into the bay; thus local vertical processes are indicated. The SST distribution suggests that the AUV survey transected a locally cold feature having along and cross-shelf scales of $\sim 15 \mathrm{~km}$. Within the section through this feature, isopycnals sloped steeply downward from the canyon to the shelf, and a wedge of high-density waters extended $\sim 6 \mathrm{~km}$ onto the shelf (Fig. 3b). The high-density wedge was relatively cold (Fig. 3c), saline, and low in chlorophyll fluorescence (Fig. 3d), oxygen and $\mathrm{pH}$.

A subsurface chlorophyll fluorescence maximum layer was centered at a depth of $\sim 10 \mathrm{~m}$ (Fig. 3d). It extended from $\sim 1.5 \mathrm{~km}$ south of the canyon, where isopycnals sloped steeply downward from the canyon, to the southern extent of the transect at $\sim 8 \mathrm{~km}$. The thickness and vertical boundaries of the layer varied significantly along the transect, however the layer closely followed isopycnals (the black contour in Fig. 3d is a reference isopycnal). Beneath the phytoplankton layer and within the wedge of high-density water was a plume of suspended particulate material (Fig. 3e). The high optical backscatter (OBS) and very low chlorophyll fluorescence of this plume indicate that the particles were not photosynthetically active phytoplankton. Elevated OBS of the plume extended from $\sim 1$ to $6 \mathrm{~km}$ alongshelf at the deep boundary of the survey. The plume signature extended from the bottom to at least the base of the phytoplankton layer, where it spanned $\sim 1 \mathrm{~km}$ alongshelf. Water column isotherms diverged by up to $\sim 25 \mathrm{~m}$ above the suspended material plume (Fig. 3c), consistent with convergence and/or vertical mixing above the plume.

The patterns observed by AUV are consistent with canyon-influenced tidal flow. The internal tide is amplified over the canyon, and the $\sim 100 \mathrm{~m}$ vertical excursions of the thermocline in this region of the bay are known to force transport of deep waters from Monterey Canyon onto the shelf (Shea \& Broenkow 1982). The shallow high-density waters over the canyon and outer shelf (0 to $1.5 \mathrm{~km}$ along transect) and the highdensity wedge containing the turbid deep shelf waters are both consistent with forcing by the locally strong internal tide. Tidal flow patterns differ along the northern and southern canyon-shelf break. While tidal ellipses along the northern canyon-shelf break are oriented along isobaths, those along the southern canyon-shelf break are oriented across isobaths, and their amplitude is greater (Petruncio et al. 1998). This suggests that the region of this AUV survey may experience particularly strong canyon-shelf exchange.

The interaction of non-tidal circulation with canyon topography is also supported. As described in the introduction, observations and model studies conclude that canyons can steer alongshore flows up-canyon. The model study by Klinck (1996) included a case appropriate to upwelling conditions over a canyon 

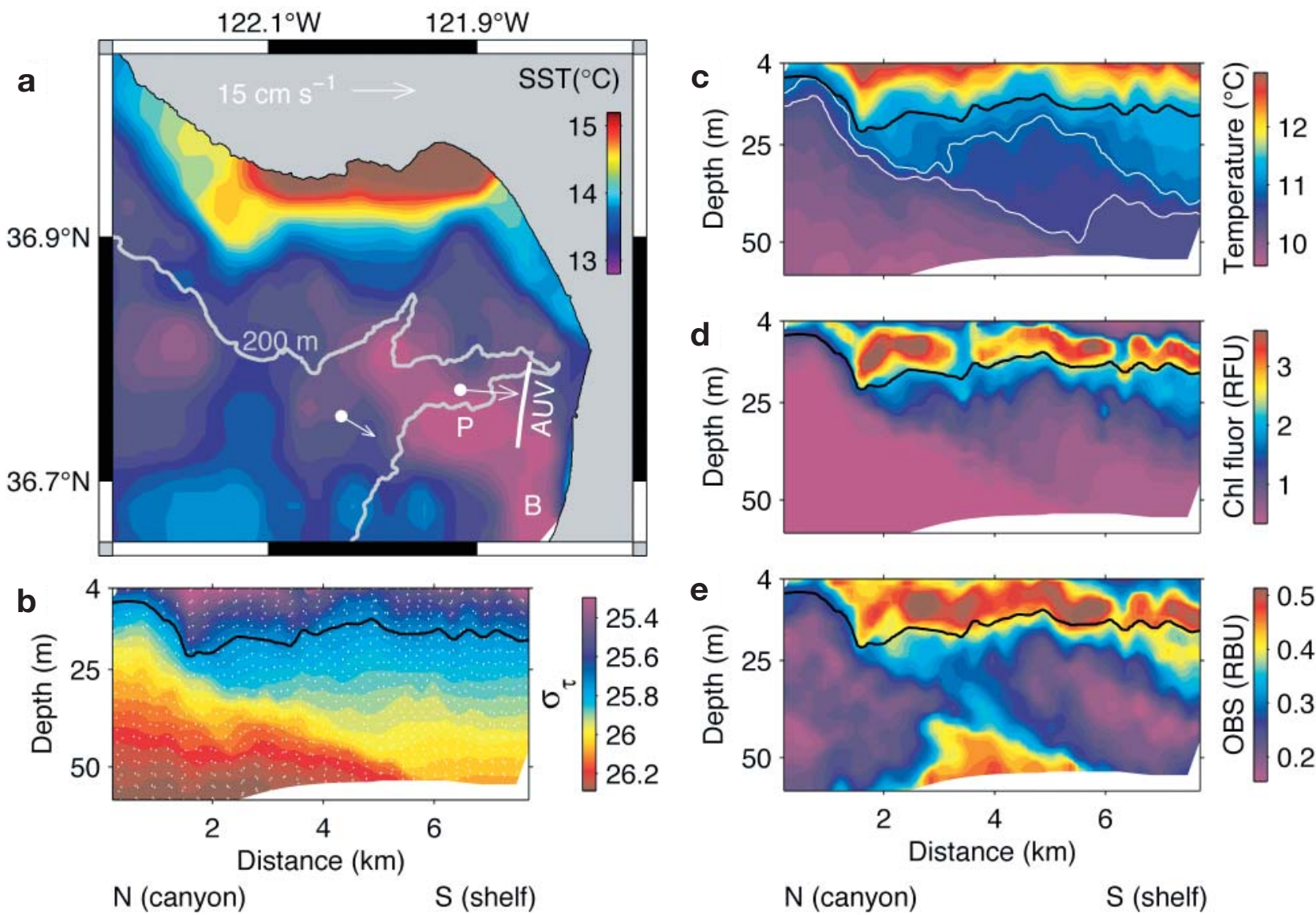

Fig. 3. (a) SST mapped by aircraft between 08:00 and 10:00 h Pacific Standard Time (PST) on August 30, 2000. Surface track of the same-day AUV survey is labeled. Labels P and B refer to a cool patch and band, respectively, described in the text. Arrows represent currents measured by ADCP below the canyon-shelf break (deeper than $200 \mathrm{~m}$ ). More seaward vector represents mean flow measured at the long-term mooring in the layer 200 to 500 m deep during August 27 to 30. Mean current was multiplied by 2 for clearer representation as a vector relative to the larger currents synoptically mapped further up-canyon. More shoreward vector represents average currents in the layer 200 to $400 \mathrm{~m}$ deep over a $1.5 \mathrm{~km} \mathrm{E-W}$ transect centered at the base of the vector. This $1.5 \mathrm{~km}$ segment represents the region of a ship transect for which deep canyon flows were consistently measured to $400 \mathrm{~m}$ deep; these currents were measured immediately before the southern shelf AUV survey of August 30, 2000. (b-e) Four of the 7 properties mapped by the AUV. All AUV profiles reached $3 \mathrm{~m}$ deep or shallower; horizontal resolution averaged 8 profiles $\mathrm{km}^{-1}$. AUV survey began $\sim 5 \mathrm{~h}$ after the aircraft SST survey and required $<2 \mathrm{~h}$ to complete. Shown in (b) over the density field is the sawtooth sampling pattern of the AUV (not shown at full vertical resolution). The $25.7 \sigma_{t}$ isopycnal is overlaid on all sections (black contour). Two isotherms are contoured in (c) to illustrate isotherm spreading over the suspended material plume. RFU and RBU are relative fluorescence and backscattering units, respectively (see 'Materials and methods')

along the northeast Pacific margin. This model case predicted steering of alongshore (southward) flow upcanyon, formation of an upwelling maximum along the downstream (southern) wall of the canyon, and formation of a cold band along the inner shelf downstream (south) of the canyon. Surface and water column observations are consistent with these model predictions.

\section{Steering of alongshore flow up-canyon}

Consistent with this model prediction are current velocities measured below the canyon-shelf break. Over the center of Monterey Canyon at the mouth of the bay, mean flow in the layer 200 to $500 \mathrm{~m}$ deep during August 27 to 30 was southward and onshore (Fig. 3a), analogous to the model case study. A ship ADCP transect up the canyon immediately preceding the shelf AUV survey showed that flow in the layer 200 to 400 m deep was up-canyon (Fig. 3a).

\section{Formation of an upwelling maximum along the downstream canyon wall}

Consistent with this model prediction is the observation of the largest patch of cool SST immediately south of the southern canyon-shelf break (labeled P in Fig. 3a). 
Formation of a cold band along the inner shelf

This model prediction results from the interaction of upwelling along the downstream (south) canyon wall and horizontal flows directed onshore and southward. Consistent with this model prediction is the observed cold band along the inner southern shelf (labeled B in Fig. 3a). Although temperature effects did not reach the surface in the model, the model shelf was flat at $100 \mathrm{~m}$ deep whereas the cold SST band observed in Monterey Bay was over a sloping shelf in waters $~ 20$ to 50 m deep.

Interaction of both tidal and non-tidal flows with Monterey Canyon may have contributed to the circulation patterns that coupled the benthic and pelagic environments on the southern shelf. Our observations are not adequate to determine the relative importance of tidal and non-tidal flow interactions with the canyon and shelf topography. Both are likely to strongly influence canyon-shelf exchange across a wide range of timescales, from the semidiurnal tide to the seasonal changes in alongshore flow that occur in this region (Breaker \& Broenkow 1994, Chavez et al. 2002).

\section{Physical-biological coupling in a frontal zone}

On August 31, the AUV volume survey in northern shelf waters revealed strong influence of frontal dynamics on phytoplankton distributions. Density and chlorophyll fluorescence within the volume are represented in Fig. 4. The isopycnal shows a ridge-trough structure in the density field. The location and orientation of this isopycnal ridge coincided with a surface slick observed from the deck of the RV 'Point Sur'. Chlorophyll fluorescence isosurfaces (green) describe boundaries of a patchy chlorophyll maximum layer (see 'Materials and methods'). The layer was contiguous throughout the volume, except where it was dispersed over the isopycnal ridge. Where evident, the layer was clearly parallel to isopycnals. North of the ridge where the isopycnal sloped gently downward, the layer was relatively homogeneous. In contrast, south of the ridge where the isopycnal sloped more sharply downward, the layer exhibited sharp vertical structure. Chlorophyll fluorescence was highest over the isopycnal trough along the southernmost section.

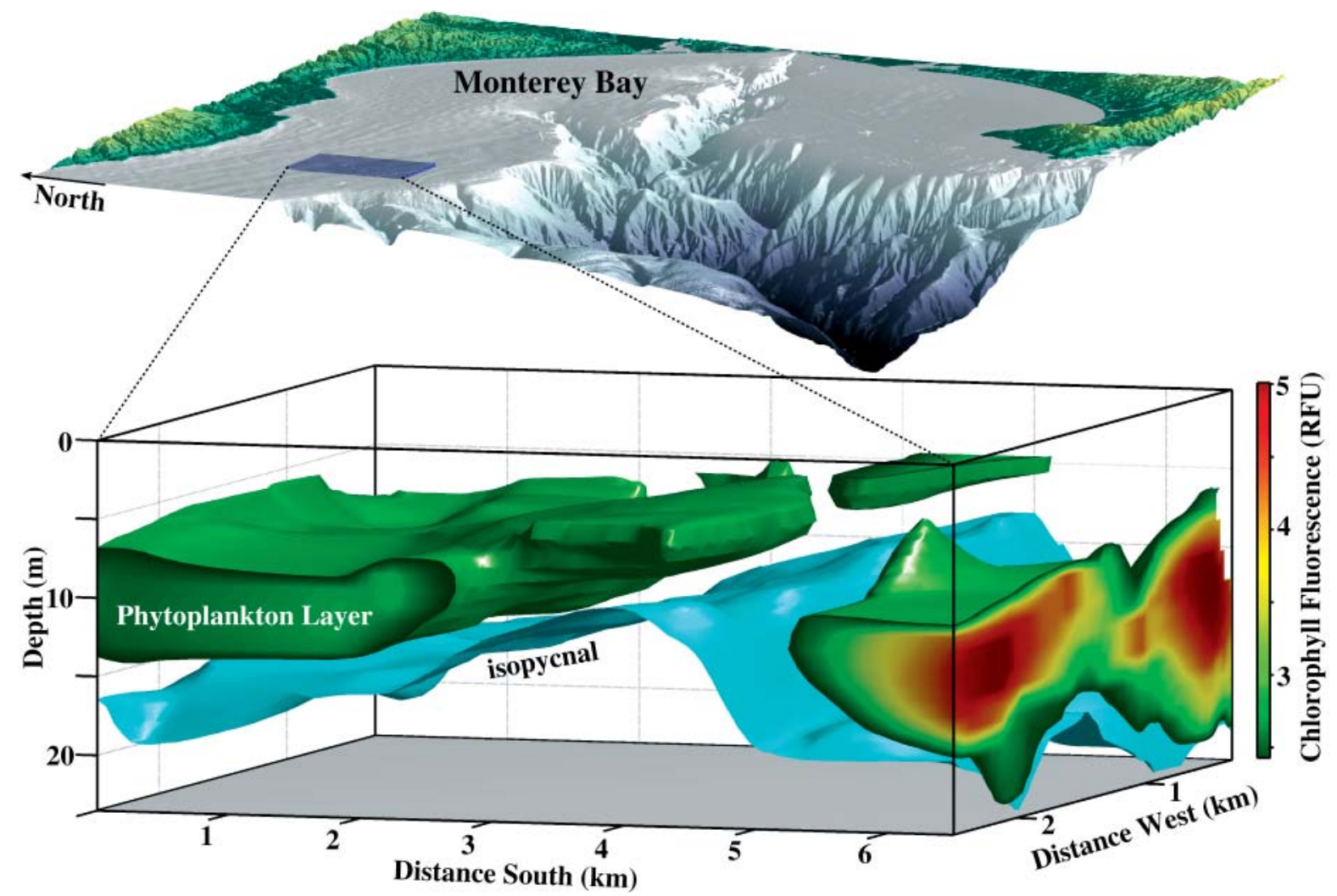

Fig. 4. Physical and bio-optical isosurfaces within a volume through a frontal zone on the northern Monterey Bay shelf, August 31, 2000. Mapping extended to $10 \mathrm{~m}$ above the bottom (maximum $70 \mathrm{~m}$ deep), but only the upper $23 \mathrm{~m}$ are shown to detail physicalbiological coupling in the upper water column through the frontal zone. Along AUV Track B (Fig. 2), 94 profiles were made within the volume. The cyan isosurface is the $25.75 \sigma_{\mathrm{t}}$ isopycnal. The green surfaces are chlorophyll fluorescence isosurfaces that define a patchy phytoplankton layer (see 'Materials and methods'). Within the isosurfaces, fluorescence was equal to or greater than the threshold value; variation above the threshold value is represented in color at the lateral boundaries of the isosurfaces. RFU is relative fluorescence units (see 'Materials and methods') 


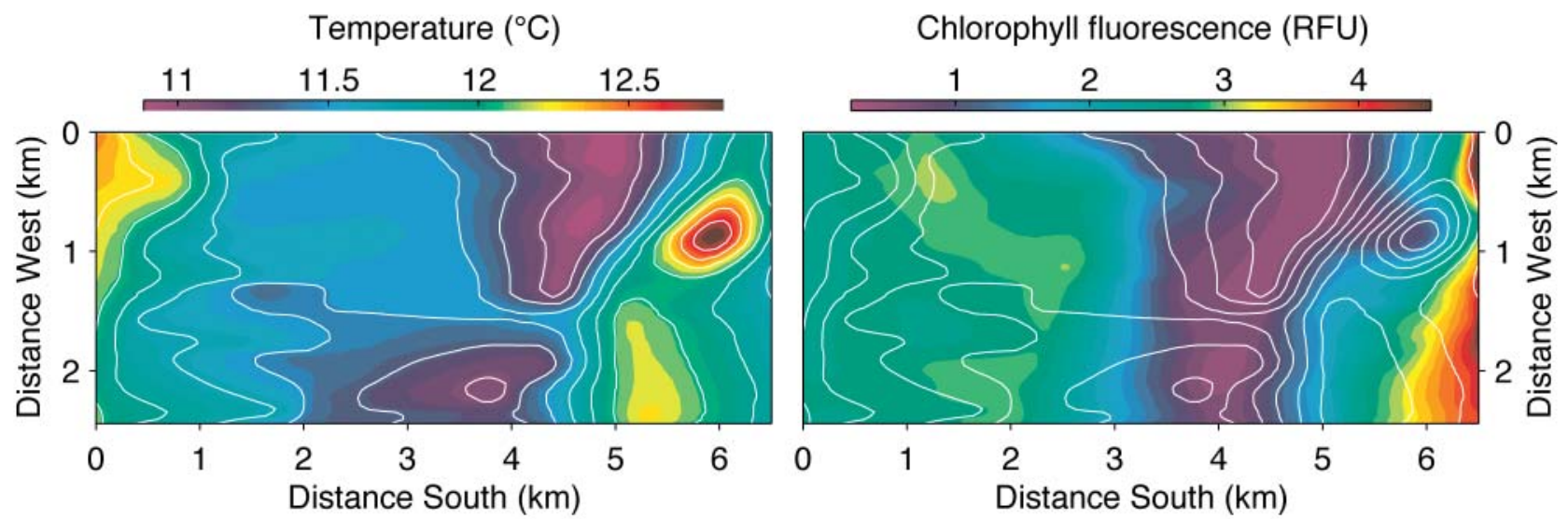

Fig. 5. Temperature and chlorophyll fluorescence at $11 \mathrm{~m}$ deep for the volume survey shown in Fig. 4. RFU is relative fluorescence units (see 'Materials and methods'). Spatial reference matches that shown for the volume. Isotherms contoured in white on the temperature map are overlaid on the chlorophyll fluorescence map

Greater detail of the frontal zone at a fixed depth is shown in Fig. 5. The coldest waters of the isopycnal ridge were centered near $3.75 \mathrm{~km}$ south along the western boundary, and near $5 \mathrm{~km}$ south along the eastern boundary. South of the cold band was a frontal zone $<1 \mathrm{~km}$ in cross-frontal scale and a warm frontal eddy $<1 \mathrm{~km}$ in diameter. The eddy, centered at $\sim 6 \mathrm{~km}$ $\mathrm{S} / 0.9 \mathrm{~km} \mathrm{~W}$, was well resolved by E-W sections along its northern and southern boundaries and a NW-SE section through its center. Chlorophyll fluorescence was lowest in the isopycnal ridge/cold band, and the chlorophyll maximum layer was evident north and south of the minimum. The fluorescence minimum extended from the frontal zone into the core of the eddy, and the highest chlorophyll fluorescence was observed along the NE periphery of the eddy. These patterns indicate influence of the eddy on the smallscale distribution of phytoplankton.

Topographic influence on phytoplankton ecology is supported by these observations of physical-biological coupling through the frontal zone. Lee waves generated by interaction of tidal flows with the shelf break are characterized by formation of an isopycnal ridge over the outer shelf during the flood tide, and these waves may propagate onshore (Mann \& Lazier 1996). The AUV survey occurred during the flood tide (Fig. 6), consistent with lee wave forcing of an isopycnal ridge. The isopycnal ridge observed on the northern shelf was aligned with the canyon-shelf break S-SW of the volume (Fig. 4), consistent with wave generation in that region of the shelf break. Internal waves are often associated with surface slicks caused by the enhanced surface tension in convergence zones where buoyant organic matter accumulates, and plankton can be concentrated in convergence zones over internal wave troughs (Zeldis \& Jillett 1982, Shanks 1983, Franks 1997, Lennert-Cody \& Franks 1999, Pineda 1999). The surface slick aligned with the northern shelf front and the presence of the highest chlorophyll fluorescence over the isopycnal trough support the role of internal wave dynamics in the physical-biological coupling observed through this frontal zone.

\section{Flow-topography interactions and phytoplankton ecology}

In both case studies of physical-biological coupling on the Monterey Bay shelf, flow-topography interactions are indicated as strong influences on the environment and spatial distribution of phytoplankton. Each case study represents processes that may persistently influence ecology in the bay.

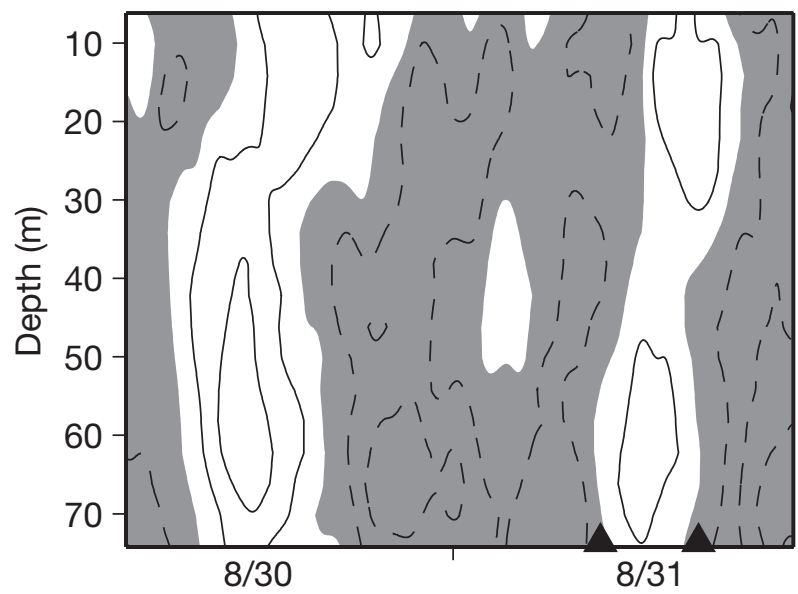

Fig. 6. Zonal currents measured at the northern shelf mooring beneath the AUV volume survey (Fig. 2). To emphasize tidal variation the original $1 \mathrm{~min}$ resolution data were low-pass filtered with a $2 \mathrm{~h}$ cutoff period. White regions indicate onshore flows of the flood tide; shaded regions indicate offshore flows. The contour interval is $5 \mathrm{~cm} \mathrm{~s}^{-1}$. Triangles at the maximum depth indicate the start and end of the AUV survey. Time reference is local (PST) 
In the first case study the flux of suspended particulate material from the deep shelf and/or canyon to the shallow euphotic zone represents 2 possible transports of ecological significance: plankton and nutrients. Shelf sediments in Monterey Bay contain resting stages of phytoplankton (Garrison 1981) whose transport into the euphotic zone will influence the plankton community. Transports from the deep shelf/canyon also supply nutrients to the euphotic zone. Iron is a limiting nutrient and an important regulator of phytoplankton productivity in this coastal upwelling system, and transport of shelf sediments into the euphotic zone is the primary process by which iron is supplied to the phytoplankton (Johnson et al. 1999, Fitzwater et al. 2003).

In the second case study, wave-like perturbation of the density field strongly modified the distribution of phytoplankton. Observations indicate dispersion of a phytoplankton layer over an isopycnal ridge/frontal eddy and concentration of phytoplankton in the adjacent trough and along the eddy periphery. Phytoplankton would be influenced by changes in the light and nutrient environment. Considering the observed wave trough, light exposure would be reduced by deeper residence of the phytoplankton and by greater selfshading that would accompany higher concentrations. Considering vertical displacement of phytoplankton on isopycnals through a series of internal wave crests and troughs, total light exposure as well as turbulent nutrient flux across the thermocline may be enhanced (Lande \& Yentsch 1988, Mann \& Lazier 1996). Foraging efficiency of zooplankton and larval fish may be enhanced by the relatively high phytoplankton concentrations in troughs. The importance of high concentrations of phytoplankton in subsurface chlorophyll maximum (SCM) layers to the survival of first-feeding fish larvae was first described for northern anchovy of the Southern California Bight (Lasker 1975). SCM layers are regularly observed in Monterey Bay, and the SCM layer observed on the northern Monterey Bay shelf was highly modified by wave and frontal dynamics. The supported mechanism underlying these dynamics, internal wave generation at the shelf break, may introduce high-frequency modulation of SCM layers that profoundly impacts plankton ecology.

These studies supporting topographically influenced physical-biological coupling may also have implications for harmful algal bloom ecology in Monterey Bay. The pennate diatom Pseudo-nitzschia australis is a prevalent harmful algal species in Monterey Bay. This species produces domoic acid, a neurotoxin harmful to marine vertebrates and causing amnesic shellfish poisoning in humans. In 1998, a bloom of $P$. australis resulted in widespread mortality of marine mammals and seabirds in coastal waters of central California (Scholin et al. 2000). Four years of surface water sampling in Monterey Bay showed maximum abundance of $P$. australis during August through November (Buck et al. 1992). During August 2000, P. australis was pre-

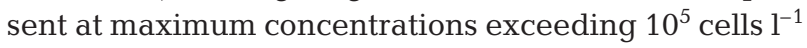
in both regions of our AUV surveys (Fig. 7). Abundance was greatest between a depth of 10 and $20 \mathrm{~m}$;
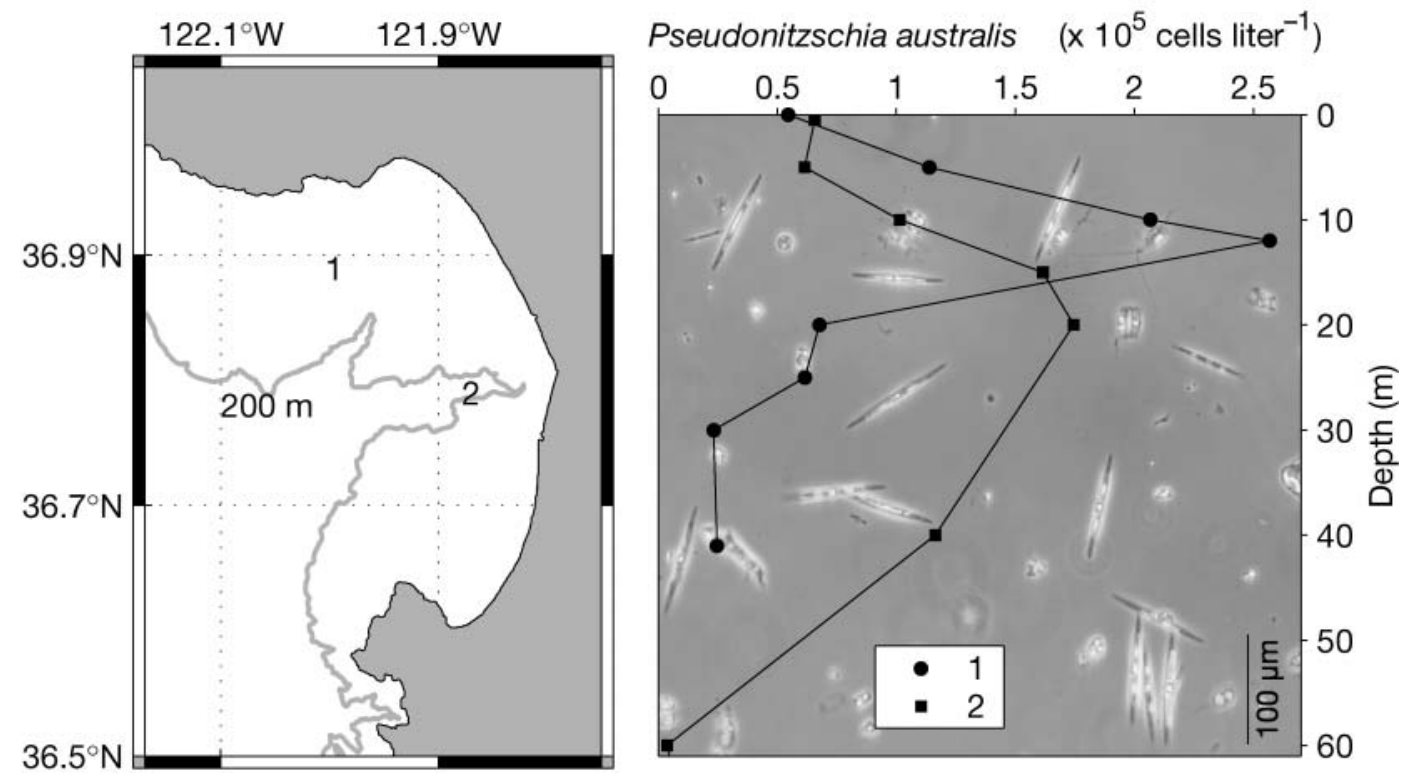

Fig. 7. Locations of 2 water sample profiles made during MUSE. Location 1 was sampled on August 25, 2000; Location 2 was sampled on August 31, 2000. Profiles of the abundance of Pseudo-nitzschia australis at the 2 stations are overlaid on an image from the $20 \mathrm{~m}$ sample of Profile 2. P. australis is the pennate diatom prevalent throughout the sample and was identified and quantified by genetic and microscopic methods (Scholin et al. 1997, 1999, 2000) 
that is, at a depth similar to the layers of maximum chlorophyll fluorescence mapped by the AUV. Concentrations exceeding $10^{5}$ cells $\mathrm{l}^{-1}$ are sufficiently high to be associated with toxic events (Bates et al. 1998). Cellular production of domoic acid in $P$. australis is influenced by trace metal concentrations and is relatively low under iron replete conditions (Maldonado et al. 2002). The benthic-pelagic coupling observed in southern shelf waters represents a process that may influence sediment and iron flux to the euphotic zone and thus toxin dynamics in $P$. australis. Within the sediments may be resting stages of diverse phytoplankton, including harmful algal species. The modification of phytoplankton concentrations observed in northern shelf waters represents influence upon trophic transfer, including transfer of toxins produced by harmful algal species.

Acknowledgements. This research was supported by the David and Lucile Packard Foundation. AUV operations were maintained by MBARI and MIT personnel: D. Gashler, H. Thomas, K. Streitlien, J. Rieffel. This manuscript is dedicated to the memory of Drew Gashler, MBARI AUV Supervisor. We thank the captain and crew of the RV 'Point Sur' for AUV operations support. The aircraft mapped SST data in Fig. 3 is from S. Ramp and J. Paduan of the Naval Postgraduate School (NPS), Monterey, CA. We thank C. Collins and F. Bahr of NPS for processing of ship and mooring ADCP data, respectively. Pseudo-nitzschia australis data and imagery shown in Fig. 7 are from C. Scholin and R. Marin of MBARI. The NOAA CoastWatch program and NASA Goddard Space Flight Center produced the satellite image data from AVHRR and SeaWiFS, respectively, shown in Fig. 1. Discussion with M. McManus aided interpretation of the AUV volume survey. Three anonymous reviewers contributed valuable suggestions for revision of the original manuscript.

\section{LITERATURE CITED}

Allen SE (1996) Topographically generated, subinertial flows within a finite length canyon. J Phys Oceanogr 26: 1608-1632

An E, Dhanak MR, Shay LK, Smith S, Van Leer J (2001) Coastal oceanography using a small AUV. J Atmos Ocean Tech 18:215-234

Barber RT, Smith RL (1981) Coastal upwelling ecosystems. In: Longhurst AR (ed) Analysis of marine ecosystems. Academic Press, New York, p 31-68

Bates SS, Garrison DL, Horner RA (1998) Bloom dynamics and physiology of domoic-acid-producing Pseudo-nitzschia species. In: Anderson DM, Cembella AD, Hallegraeff GM (eds) Physiological ecology of harmful algal blooms. Springer-Verlag, New York, p 267-292

Bellingham, JG (1997) New oceanographic uses of autonomous underwater vehicles. Mar Technol Soc J 31:34-47

Breaker LC, Broenkow WW (1994) The circulation of Monterey Bay and related processes. Oceanogr Mar Biol Annu Rev 32:1-64

Brewer PG, Moore T (eds) (2001) Ocean Sciences at the New Millennium. University Corp Atmos Res, available at www.joss.ucar.edu/joss_psg/publications/decadal/
Brierley AS, Fernandes PG, Brandon MA, Armstrong F and 8 others (2002) Antarctic krill under sea ice: elevated abundance in a narrow band just south of the edge. Science 295:1890-1892

Buck KR, Uttal-Cooke L, Pilskaln CH, Roelke DL, Villac MC, Fryxell GA, Cifuentes L, Chavez FP (1992) Autecology of the diatom Pseudonitzschia australis, a domoic acid producer, from Monterey Bay, California. Mar Ecol Prog Ser 84:293-302

Chavez FP, Pennington JT, Castro CG, Ryan JP and 6 others (2002) Biological and chemical consequences of the 1997-98 El Niño in central California waters. Prog Oceanogr 54(1-4):205-232

Chavez FP, Ryan J, Lluch-Cota SE, Niquen M (2003) From anchovies to sardines and back: multidecadal change in the Pacific Ocean. Science 299(5604):217-221

Fitzwater SE, Johnson KS, Elrod VA, Ryan JP, Coletti LJ, Tanner SJ, Gordon RM, Chavez FP (2003) Iron, nutrient and phytoplankton biomass relationships in upwelled waters of the California coastal system. Cont Shelf Res 23:1523-1544

Franks PJS (1997) Spatial patterns in dense algal blooms. Limnol Oceanogr 42:1297-1305

Freeland HJ, Denman KL (1982) A topographically controlled upwelling off southern Vancouver Island. J Mar Res 40: 1069-1093

Freeland H, McIntosh P (1989) The vorticity balance on the southern British Columbia continental shelf. Atmos Ocean 27:643-657

Garrison DL (1981) Monterey Bay phytoplankton. II. Resting spore cycles in coastal diatom populations. J Plankton Res 3(1):137-156

Johnson KS, Chavez FP, Friederich GE (1999) Continentalshelf sediment as a primary source of iron for coastal phytoplankton. Nature 398(6729):697-700

Klinck JM (1996) Circulation near submarine canyons: a modeling study. J Geophys Res 101:1211-1223

Kudela, RM, Chavez FP (2000) Modeling the impact of the 1992 El Niño on new production in Monterey Bay, California. Deep-Sea Res II 47:1055-1076

Kunze E, Rosenfeld LK, Carter GS, Gregg MC (2002) Internal waves in Monterey Submarine Canyon. J Phys Oceanogr 32:1890-1913

Lande R, Yentsch CS (1988) Internal waves, primary production and the compensation depth of marine phytoplankton. J Plankton Res 10:565-571

Lasker R (1975) Field criteria for the survival of anchovy larvae: the relation between inshore chlorophyll maximum layers and successful first feeding larvae. Fish Bull US 73:847-855

Lennert-Coty CE, Franks PJS (1999) Plankton patchiness in high-frequency internal waves. Mar Ecol Prog Ser 186: 59-66

Maldonado MT, Hughes MP, Rue EL, Wells ML (2002) The effect of $\mathrm{Fe}$ and $\mathrm{Cu}$ on growth and domoic acid production by Pseudo-nitzschia multiseries and Pseudo-nitzschia australis. Limnol Oceanogr 47(2):515-526

Mann KH, Lazier JRN (1996) Dynamics of marine ecosystems: biological-physical interactions in the oceans, 2nd edn. Blackwell Science, Boston, MA

Matthews BM, Johnson KS (2001) The MBARI upperwater-column science experiment, a precedent in multidisciplinary, multi-institute collaboration. Sea Technol Sept:1-3

Nadis S (1997) 'Real-time' oceanography adapts to sea changes. Science 275:1881-1882

Olivieri RA, Chavez FP (2000) A model of plankton dynamics 
for the coastal upwelling system of Monterey Bay, California. Deep-Sea Res II 47:1077-1106

Owens WB, Millard RC (1985) A new algorithm for CTD oxygen calibration. J Phys Oceanogr 15:621-631

Pennington JT, Chavez FP (2000) Seasonal fluctuations of temperature, salinity, nitrate, chlorophyll and primary production at station H3/M1 over 1989-1996 in Monterey Bay, California. Deep-Sea Res II 47:947-973

Petruncio ET, Rosenfeld LK, Paduan JD (1998) Observations of the internal tide in Monterey Canyon. J Phys Oceanogr 28:1873-1903

Pineda J (1999) Circulation and larval distribution in internal tidal bore warm fronts. Limnol Oceanogr 44(6):1400-1414

Ramp SR, Paduan JD, Shulman I, Kindle J, Barr FL, Chavez FP (2005) Observations of upwelling and relaxation events in the northern Monterey Bay during August 2000. J Geophys Res (in press)

Ryther JH (1969) Photosynthesis and fish production in the sea. Science 166:72-76

Scholin CA, Miller P, Buck K, Chavez FP, Harris P, Haydock P, Howard J, Cangelosi G (1997) Detection and quantification of Pseudo-nitzschia australis in cultured and natural populations using LSU rRNA-targeted probes. Limnol Oceanogr 42:1265-1272

Scholin CA, Marin R, Miller P, Doucette G, Powell C, Howard J, Haydock P, Ray J (1999) Application of DNA probes and a receptor binding assay for detection of Pseudo-nitzschia (Bacillariophyceae) species and domoic

Editorial responsibility: Barry and Evelyn Sherr (Contributing Editors), Corvallis, Oregon, USA acid activity in cultured and natural samples. J Phycol 35:1356-1367

Scholin CA, Gulland F, Doucette GJ, Benson S and 22 others (2000) Mortality of sea lions along the central California coast linked to a toxic diatom bloom. Nature 403:80-84

Service SK, Rice JA, Chavez FP (1998) Relationship between physical and biological variables during the upwelling period in Monterey Bay, CA. Deep-Sea Res II 45:1669-1685

Shanks AL (1983) Surface slicks associated with tidally forced internal waves may transport pelagic larvae of benthic invertebrates and fishes shoreward. Mar Ecol Prog Ser 13: 311-315

Shea RE, Broenkow WW (1982) The role of internal tides in the nutrient enrichment of Monterey Bay, California. Estuar Coast Shelf Sci 15:57-66

Stansfield K, Smeed DA, Gasparini GP, McPhail S and 5 others (2001) Geophys Res Lett 28:2645-2648

Yu X, Dickey T, Bellingham J, Manov D, Streitlien K (2002) The application of autonomous underwater vehicles for interdisciplinary measurements in Massachusetts and Cape Cod Bays. Cont Shelf Res 22:2225-2245

Zeldis JR, Jillett JB (1982) Aggregation of pelagic Munida gregaria (Fabricius) (Decapoda, Anomura) by coastal fronts and internal waves. J Plankton Res 4:839-857

Zhang Y, Streitlien K, Bellingham JG, Baggeroer AB (2001) Acoustic doppler velocimeter flow measurement from an autonomous underwater vehicle with applications to deep ocean convection. J Atmos Ocean Technol 18:2038-2051

Submitted: January 15, 2004; Accepted: July 23, 2004 Proofs received from author(s): February 8, 2005 